\title{
British Virgin Islands: Financial Sector Assessment Program Update Documentation- Technical Note on Mutual Fund Regulation
}

This Technical Note on Mutual Fund Regulation for British Virgin Islands was prepared by a staff team of the International Monetary Fund as background documentation for the periodic consultation with the member country. It is based on the information available at the time it was completed in April 2010. The views expressed in this document are those of the staff team and do not necessarily reflect the views of the government of British Virgin Islands or the Executive Board of the IMF.

The policy of publication of staff reports and other documents by the IMF allows for the deletion of market-sensitive information.

Copies of this report are available to the public from

International Monetary Fund $\bullet$ Publication Services

700 19th Street, N.W. • Washington, D.C. 20431

Telephone: (202) 6237430 • Telefax: (202) 6237201

E-mail: publications@imf.org • Internet: http://www.imf.org

\section{International Monetary Fund Washington, D.C.}


FINANCIAL SECTOR ASSESSMENT PROGRAM

BRITISH VIRGIN ISLANDS

MutuAl Fund REgUlATION

TECHNICAL NOTE

OCTOBER 2010

INTERNATIONAL MONETARY FUND

MONETARY AND CAPITAL MARKETS DEPARTMENT 


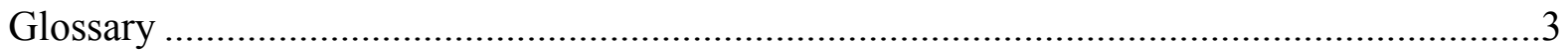

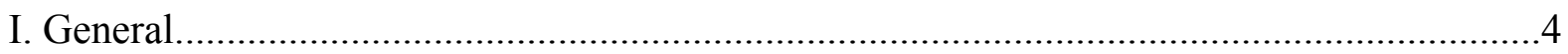

II. Information and Methodology Used for Review ……...................................................

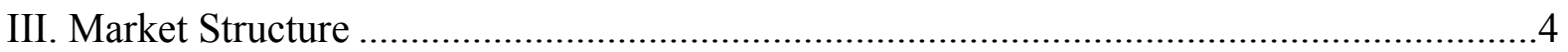

IV. Summary of Findings of Previous Assessment ………................................................

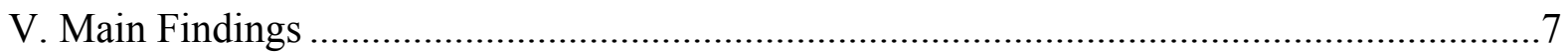

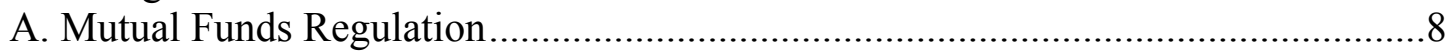

B. Summary Update of Assessment of Other Key Areas

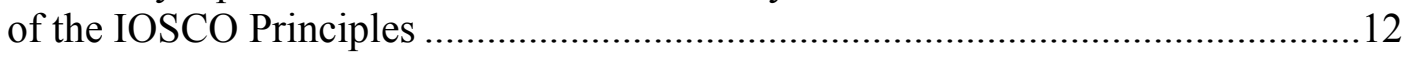

Tables

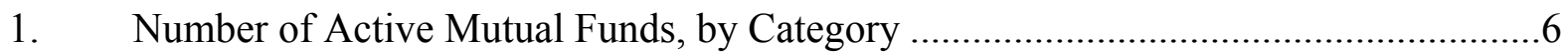

2. Number of Active Fund Managers and Administrators by Category ............................ 


\section{GLOSSARY}

$\begin{array}{ll}\text { AML } & \text { Anti-Money Laundering } \\ \text { BCA } & \text { BVI Business Companies Act, 2004 } \\ \text { BVI } & \text { British Virgin Islands } \\ \text { FSICA } & \text { Financial Services (International Cooperation) Act, 2000 } \\ \text { FSC } & \text { Financial Services Commission } \\ \text { FSCA } & \text { Financial Services Commission Act, 2001 (as amended) } \\ \text { IBCA } & \text { International Business Companies Act, 1984 } \\ \text { IFRS } & \text { International Financial Reporting Standards } \\ \text { IOSCO } & \text { International Organization of Securities Commissions } \\ \text { IOSCO MMOU } & \text { IOSCO Multilateral MOU Concerning Consultation and } \\ \text { Cooperation and the Exchange of Information } \\ \text { IOSCO Principles } & \text { IOSCO Objectives and Principles of Securities Regulation } \\ \text { MD } & \text { Managing Director of the FSC } \\ \text { MF Act } & \text { Mutual Funds Act, 1996 } \\ \text { MFAR } & \text { Mutual Fund Annual Return } \\ \text { MOU } & \text { Memorandum of Understanding } \\ \text { SIBA } & \text { Securities and Investment Business Act, 2010 }\end{array}$




\section{Mutual Fund Regulation}

\section{General}

1. The BVI's regulatory system was originally assessed for its observance of the IOSCO Objectives and Principles of Securities Regulation (the IOSCO Principles) as part of an IMF Offshore Financial Centre mission to the BVI during November 2002 (the previous assessment). This report is an update of the previous assessment with a focus on the regulation of mutual funds, which is the only securities activity of importance in the jurisdiction. The assessment was undertaken by Tanis MacLaren, consultant to the IMF.

\section{INFORMATION AND METHODOLOGY USED FOR REVIEW}

2. The observations in this report were based on several sources. The assessor conducted interviews with staff of the FSC and individual industry members, a review of the laws, regulations, codes, guidance, and procedures with respect to the securities regulatory regime, various draft instruments and the self-assessment provided by the FSC. The assessor used the relevant parts of the IOSCO Methodology for Assessing the Implementation of the IOSCO Objectives and Principles of Securities Regulation.

3. The staff of the FSC accommodated the demands for information and interviews, and they adjusted their schedules to respond in a timely fashion. They were candid and open to discussions of areas where more authority, resources, or other enhancements might be desirable. Representatives of the industry and the professions were also helpful in providing additional information and perspective.

\section{MARKet Structure}

4. The FSC is an independent supervisory authority with broad authority to regulate the full scope of financial services presently offered from or in the BVI. The FSC was created as a supervisory agency under the Financial Services Commission Act, 2001 (the FSCA). The FSCA gives the FSC the authority to administer, enforce, carry out, and give effect to the provisions of the laws related to the financial services in the BVI. The FSC has the responsibility and authority to grant and revoke the licenses of banks, insurance companies, mutual fund managers and administrators, trust companies, and company service providers. It is also the authority responsible for the incorporation of companies under the BVI Business Companies Act, 2004 (BCA). The FSCA authorizes the FSC to conduct examinations of regulated persons and corporations, to impose levies, and to impose and collect fees. The legal system in the BVI operates under common law principles.

5. The regulation of securities in the BVI was introduced with Mutual Funds Act, 1996 (the MF Act), which was implemented in January 1997. The MF Act provides for the registration of public mutual funds and the recognition of private and professional funds. It also governs the licensing of mutual fund managers and mutual fund administrators operating in or from the BVI. 
6. The regulatory framework established by the legislation and related regulations has been supplemented by the enactment of the Regulatory Code, effective in December 2009. In order to provide a more flexible regime that can be adapted quickly to market developments, the FSC has been given the statutory authority to issue legally binding codes. The Regulatory Code contains more detailed requirements that support the general framework established by the primary legislation. The Regulatory Code includes requirements of general application to all types of licensees, such as fit-and-proper criteria; minimum books and records; risk management and internal control requirements; accounting and auditing standards; requirements for financial statements; and obligations regarding protection of customer assets. There are also detailed sector-specific rules for banks, trust companies, and insurance companies. Once the Securities and Investment Business Act, 2010 (SIBA) is in force, a new Part will be added to the Code to address investment business intermediaries.

7. On the first day of the mission, SIBA - an act to modernize the regulation of mutual funds and investment business - was passed by the legislature. SIBA:

- $\quad$ expands the categories of investment activities subject to licensing to include the full array of intermediary activities and sets general requirements for these firms;

- $\quad$ introduces requirements for the public issue of securities other than mutual funds;

- $\quad$ codifies and modernizes the regulation of mutual funds and their service providers;

- $\quad$ introduces general requirements for licensees to have authorized representatives in the jurisdiction and sets requirements for audited financial statements prepared by approved auditors; and

- $\quad$ addresses market abuse and outlines offences such as insider trading and market manipulation.

The general requirements will be supplemented by regulations and provisions in the Regulatory Code. The legislation also authorizes the FSC to create other codes to address specific areas, such as the Public Funds Code that covers prospectus disclosure; asset valuation; segregation of fund assets; and other issues related to the regulation of funds offered to the public. A draft of the proposed Mutual Fund Regulations and Public Funds Code was reviewed.

\section{The FSCA and the MF Act provide the main legal framework for the} supervision of securities activities in the BVI. At the time of the previous assessment, this legislation was supplemented by the Financial Services (International Cooperation) Act, 2000 (FSICA), which set out detailed requirements for information sharing with foreign regulators and foreign law enforcement agencies. In response to concerns raised during discussions of international cooperation initiatives and the process of negotiating becoming a signatory to the IOSCO Multilateral Memorandum of Understanding (IOSCO MMOU), the FSICA was repealed in 2006. The FSCA was amended to 
incorporate information-sharing provisions that expanded and clarified the FSC's authority. When SIBA is in force and the related regulations and amendments to the Regulatory Code are in place, the MF Act will be repealed.

9. At the present time, the principal securities activities in BVI are the incorporation and authorization of mutual funds. At the end of December 2009, there were a total of 2,937 active mutual funds registered or recognized in the BVI, down just slightly from 2,953 at the end of 2008. This is an increase of 23.8 percent over the past five years. Only 7.4 percent of the funds authorized by the FSC are public mutual funds that may be sold by prospectus to any investor. The rest are either professional funds (sold to sophisticated purchasers only) or private funds, where offers to the public are prohibited and the number of investors must be fewer than 50. In practice, even the public funds do not make their securities available for purchase in the jurisdiction.

\section{Table 1. British Virgin Islands: Number of Active Mutual Funds, by Category}

(As at December 31)

\begin{tabular}{|c|c|c|c|c|c|c|c|}
\hline \multirow[b]{2}{*}{ Category } & \multirow[b]{2}{*}{2005} & \multirow[b]{2}{*}{2006} & \multirow[b]{2}{*}{2007} & \multirow[b]{2}{*}{2008} & \multirow[b]{2}{*}{2009} & \multicolumn{2}{|c|}{2009} \\
\hline & & & & & & $\begin{array}{l}\text { \% of } \\
\text { Total } \\
\text { Funds }\end{array}$ & $\begin{array}{c}\% \% \\
\text { Increase } \\
2005-09\end{array}$ \\
\hline $\begin{array}{l}\text { Professional Mutual } \\
\text { Funds }\end{array}$ & 1,376 & 1,530 & 1,694 & 1,894 & 1,905 & 64.9 & 38.4 \\
\hline Private Mutual Funds & 799 & 832 & 815 & 831 & 816 & 27.8 & 2.1 \\
\hline Public Mutual Funds & 197 & 209 & 222 & 228 & 216 & 7.4 & 9.6 \\
\hline Total & 2,372 & 2,571 & 2,731 & 2,953 & 2,937 & & 23.8 \\
\hline
\end{tabular}

Source: FSC.

10. The FSC, under the MF Act, also licenses mutual fund administrators and managers operating in or from the jurisdiction. As of the end of 2009, 573 licenses had been granted. Mutual funds authorized by the FSC are not required to have managers or administrators that are licensed in the jurisdiction. Very few of the licensed managers or administrators are physically located in the BVI. SIBA will give the FSC authority to regulate other market participants, such as brokers, dealers, and underwriters.

11. There is no stock exchange in the BVI, nor is there any facility for the issue of securities other than mutual funds. There is no retail market for securities of any kind in the jurisdiction. The BVI Association of Mutual Fund Practitioners, a trade association, was formed in late 2001. There are no self-regulatory organizations in the BVI. 
Table 2. British Virgin Islands: Number of Active Fund Managers and
Administrators, by Category

As at December 31

\begin{tabular}{lrrrrrrr}
\hline Category & 2005 & 2006 & 2007 & 2008 & 2009 & $\begin{array}{c}\text { \% Increase 2005- } \\
2009\end{array}$ \\
\hline Management Services & 428 & 455 & 467 & 496 & 491 & 14.7 \\
Management and & & & & & & $(10.0)$ \\
Administrative Services & 50 & 49 & 46 & 46 & 45 & 2.8 \\
Administrative Services & 36 & 37 & 36 & 39 & 37 & $\mathbf{1 1 . 5}$ \\
Total & $\mathbf{5 1 4}$ & $\mathbf{5 4 1}$ & $\mathbf{5 4 9}$ & $\mathbf{5 8 1}$ & $\mathbf{5 7 3}$ & \\
\hline
\end{tabular}

Source: FSC.

\section{Summary of Findings of Previous Assessment}

12. The previous assessment concluded that the BVI regulatory system governing securities markets functioned well overall, but required improvement in certain areas. Legislation and guidelines provided a sound foundation for regulation, and the FSC had the authority it requires to carry out its regulatory functions with respect to the segments of the securities industry operating in or from the BVI. The most pressing issue was the need to implement an effective system of supervision of mutual funds and their functionaries and to add resources to carry out enforcement activities. The other significant areas where improvements were needed related to:

- $\quad$ prospectus and other disclosure requirements for public funds;

- $\quad$ strengthening business conduct rules, and books and records, internal controls, and risk management systems requirements for mutual fund managers and mutual fund administrators; and

- $\quad$ enhanced segregation requirements for assets held for mutual funds.

\section{Main Findings}

13. Most of the significant areas requiring improvement identified in the previous assessment will be addressed with the full implementation of the Regulatory Code, SIBA, related regulations, and the Public Funds Code. However, until all of these instruments come into effect in full and are enforced, only the previous assessment's recommendations with respect to on-site inspections and additional enforcement resources can be considered implemented. Without the full and effective implementation of the new regime, the jurisdiction continues to be only partially implemented with respect to the IOSCO Principles relating to collective investment schemes (mutual funds). 


\section{Priority should be given to prompt and full implementation of the} Regulatory Code and the SIBA regime. Many of the reforms set out in these instruments were stated to be imminent at the date of the previous review. The Regulatory Code was only introduced in December 2009 (and does not contain any special provisions governing investment business) and SIBA was passed by the legislature on the first day of the mission. Also, full implementation includes being seen to be actively enforcing the new requirements on the marketplace.

\section{There still are areas where improvements are required, particularly with} respect to continuous disclosure obligations of public mutual funds. The public disclosure of material changes should be more timely (14 days is too long a period), as should the deadline for filing audited financial statements (six months is two to three months longer than the deadline in major jurisdictions).

\section{A. Mutual Funds Regulation}

16. The standards and eligibility of those who wish to manage or administer a mutual fund are determined by the FSC under the authority granted by statute. The eligibility criteria for operators include fit-and-proper requirements and appropriate operational resources and controls that are assessed prior to licensing. The application review process is detailed and comprehensive. The Regulatory Code requires licensees, including operators of mutual funds, to maintain an adequate system of internal controls appropriate to the nature and size of its business. The legislation does not require foreign incorporated managers and administrators whose operations are based entirely in a foreign jurisdiction to be registered even though the manager or administrator may act for a BVI constituted fund. Under SIBA, all of the functionaries of a public fund (manager, administrator, investment advisor, trustee and custodian) must meet the FSC's fit and proper criteria.

\section{The FSC has clear statutory powers to carry out key regulatory functions. It} has the authority to:

- $\quad$ register a public mutual fund and recognize private and professional funds;

- $\quad$ require a custodian and that it be functionally independent from the manager/administrator;

- $\quad$ conduct compliance audits to ensure eligibility criteria and other regulatory requirements continue to be met; and

- $\quad$ require disclosure of material facts.

It also has authority to investigate and take remedial and enforcement action against both licensed and unlicensed operators for breaches of regulatory requirements. The maximum fines available under the MF Act are not very high and, while the maximum fines increase under SIBA, the amounts may be too low to be an effective deterrent. Consideration should be given to increasing these fines. 
18. The reporting and other requirements for mutual funds and licensed service providers have increased since the last assessment. The Regulatory Code requires fund managers and administrators to file annual audited financial statements and imposes general books and records, internal control and risk management requirements. Since 2008, the FSC requires the filing of a Mutual Fund Annual Return (MFAR) by all registered or recognized funds. These requirements address weaknesses identified in the previous assessment.

\section{Until SIBA and the Public Funds Code are fully in force, there are no} detailed rules for conflicts of interest for public funds. The draft Public Funds Code requires disclosure of material conflicts of interest and how they will be managed. The Regulatory Code requires licensees to manage conflicts of interest fairly. The provision of additional requirements governing conflicts of interest is consistent with recommendations made in the previous assessment.

20. The Regulatory Code provides a framework for delegation/outsourcing by licensees that is consistent with international standards. Outsourcing is prohibited if it would negatively affect the rights of customers against the licensee. Tasks may be outsourced, but responsibilities may not. The licensee may not outsource the responsibility for delivery of services to its customers. Both regulators and clients must know who is carrying on the licensee's activities and the licensee must ensure the regulator continues to have the access needed to oversee those activities.

21. A mutual fund can be organized as a corporation, unit trust, or partnership under BVI law (or other law). Most funds authorized in the jurisdiction are incorporated under the BCA. The legal form of the fund would be expected to be described in the prospectus of the fund that is vetted by the FSC. Under the draft Public Funds Code, this information would be required to be provided in the prospectus, as would a description of any related risk factors.

22. The Regulatory Code sets out general obligations on licensees for customer assets protection. Customer assets are to be indentified and segregated. Customer money must not be commingled with that of the licensee. Appropriate safekeeping arrangements must be in place and detailed records kept. The Regulatory Code only applies to BVIlicensed administrators and managers. The Public Funds Code under SIBA would impose similar requirements for books and records, and segregation of fund property and investors' assets on all public mutual funds, regardless of the licensing status of the fund's manager or administrator in the jurisdiction.

23. The custodian must be functionally independent of the fund manager and fund administrator. Under the MF Act and the Public Funds Code, the custodian cannot be the party responsible for investment decisions. Functional independence is not defined. Consideration should be given to providing clear guidance on the indicia of functional independence to ensure the maximum separation of the functions possible. In practice, most custodians are separate companies and are banks or trust companies. Very few, if any, custodians are BVI-domiciled companies. The prospectus of the fund is expected to include details regarding the custodian, including its key personnel and 
experience, terms of appointment, and termination. This information would be required to be included in a prospectus under the Public Funds Code.

24. There are general prospectus requirements under the MF Act, but they lack detail. Until SIBA is proclaimed and the Public Funds Code is operational, there are no provisions that set detailed requirements for the contents of a prospectus of a public fund. The MF Act provides that all public funds must publish a prospectus, the contents of which are approved by the fund's governing body. Under the MF Act and SIBA, every prospectus must provide full and accurate disclosure of all such information as investors would reasonably require and expect to find for the purpose of making an informed decision. SIBA and the draft Public Funds Code require the disclosure of the full range of information expected by the IOSCO Principles. As a matter of administrative practice, the Investment Business Division has developed a checklist for the contents of a prospectus and against which all prospectuses of public funds are evaluated. This disclosure includes similar information to that required under the Public Funds Code.

25. The continuous disclosure obligations imposed on public funds are minimal and any disclosure required is not very timely. Under current practices, any material change in the information set out in the prospectus must be reflected in an amended prospectus that must be published within 14 days of the change. The amended prospectus must be filed with the FSC and provided to each of the fund's investors. These provisions continue under SIBA. This 14-day time frame is too slow. Mutual funds should be subject to continuous disclosure requirements to make immediate public disclosure of any material changes and to make these changes known to investors. Consideration might be given to posting such notices on the FSC website. The prospectus should be amended promptly and filed with FSC as soon as practicable after the change.

26. Financial disclosure requirements have been increased since the last assessment, but the timeframe for disclosure is slow by international standards. The MF Act and SIBA provide that all public funds must provide or make available annual audited fund reports and accounts to all of their investors. The Regulatory Code sets acceptable accounting principles and auditing standards that must be used and the standards specified are internationally recognized ones. Audited financial statements must be filed with the FSC within six months of the public fund's year end, which is very slow by international standards. This period should be shortened substantially; 90 days to 120 days is more in keeping with practices in the major jurisdictions for public funds. The legislation should prescribe when the financial statements have to be made available to investors. There is no requirement for audited statements of net asset value or for a portfolio summary, although SIBA contains authority for additional statements to be prescribed in the Mutual Fund Regulations. SIBA also contains provision for requiring public funds to provide interim financial statements. International best practices would require interim statements be filed with the regulator and made public not less than semi-annually.

27. The publication of a prospectus must be authorized by the directors of the mutual fund, and they are responsible for certifying the truth and completeness of the statements made. The MF Act and SIBA impose liability on the mutual fund and the 
members of the Board who were aware of any misrepresentation or would have been aware if they had made a reasonable investigation. No one else (underwriters, auditors, lawyers, other experts) who may have been involved in the preparation of the prospectus or the statements made in the prospectus are liable under this section. These persons may be liable at common law for negligent misrepresentation. The liability for misrepresentations in the prospectus should be extended to all parties involved in preparing or authorizing the prospectus. In particular, the liability should extend to the lawyers and auditors involved. Under SIBA this wider network of people would be liable for misrepresentations in a prospectus of a public issuer other than a mutual fund.

28. Until SIBA is proclaimed and the Public Funds Code is operational there are significant gaps in the requirements relating to asset valuation and pricing and redemption of mutual fund securities. There are no specific requirements that relate to:

- $\quad$ fair and accurate valuation of investments and correct calculation of net asset value;

- $\quad$ the provision of information about asset value and pricing policies in a manner that allows investors and others to accurately assess performance over time;

- the consistent use of a set of accounting rules and disclosure of which accounting rules are used in the valuation;

- the minimum frequency of valuation.

These matters are addressed in the requirements set out in the Public Funds Code as presently drafted. Under the Code, asset valuations and net asset value calculations are required to be conducted by parties independent of the fund manager and verified at least on an annual basis by the fund's auditor. At the present time, when vetting a public fund's application for registration, the Investment Business Division's checklist requires that a fund's prospectus provide for disclosure of information about the asset valuation process, where information regarding the value of an investor's investment can be found, and the subscription and redemption process.

29. The FSC has broad powers to ensure compliance with the requirements of the legislation, regulations, and codes, including those relating to valuations. The FSC compliance review program of fund administrators requires a detailed assessment of the valuation, subscription, and redemption practices of these licensees. Changes and limitations on redemption rights are not subject to prior approval of the $\mathrm{FSC}$, but it must be notified. Under the FSCA, the FSC may issue directives requiring a regulated person to take such action as the FSC considers necessary to protect the property of the fund or to protect customers or creditors. The FSC has used this power to direct the suspension of redemption payments by funds. 


\section{B. Summary Update of Assessment of Other Key Areas of the IOSCO Principles}

30. The FSC is operationally independent and has extensive authority to carry out its responsibilities. The responsibilities of FSC are clear and objective. While independent, it is publicly accountable to the government and to the courts in the exercise of its functions. The staff of the FSC meets high expectations of professionalism in their work. The processes followed are clear and consistently applied. All of the laws, regulations that FSC administers and the relevant codes and guidelines made by the FSC are publicly available on the FSC website. Since the last assessment, the inclusiveness of the consultation process has been enhanced by meeting not only with local market participants, but by posting drafts of documents on the website to facilitate input from offshore parties.

31. Upon full implementation of SIBA, the FSC will have authority over public issuers, market intermediaries, and market-abuse matters. These gaps were noted in the previous assessment.

32. The FSC has a comprehensive array of inspection, investigation, surveillance, and enforcement powers. These powers were enhanced in 2006 to include, inter alia, the authority to take action against persons carrying on financial services activities without the requisite license. The previous assessment noted that the monetary penalties imposed for a breach of the law were not high enough to be an effective deterrent and should be reexamined. The fines under SIBA are higher than those under the FSCA (maximum of $\$ 2,000$ to $\$ 20,000$ ) or the MF Act (maximum of $\$ 5,000$ to $\$ 50,000$ ), but still only range from a maximum of $\$ 15,000$ to $\$ 75,000$, which are not large sums of money for entities engaged in the financial services business. Consideration should be given to increasing these amounts, so that they provide meaningful deterrents to international financial market participants. Consideration should also be given to imposing greater transparency on the enforcement process by routinely publishing details of enforcement actions taken and sanctions imposed.

33. A comprehensive system of on-site and off-site inspections of licensed entities located in the jurisdiction has been established. This was the most significant weakness in supervision identified in the previous review. An on-site inspection program was implemented in 2008. Thirteen examinations were completed by the end of 2009, which constitutes approximately a third of the firms located in the jurisdiction. The onsite inspection program covers all aspects of the licensees' business and compliance with FSC requirements. The implementation of a system to follow up on inspection report recommendations to ensure that licensees fulfill their obligations in a timely fashion would assist in the effectiveness of the inspection program. All documents and reports filed by licensees and funds (located on or offshore are subject to detailed review by FSC staff.

34. The information available to the FSC on regulated firms and mutual funds has been enhanced. The FSCA has been amended to provide extensive authority to the FSC to require the filing of reports by regulated persons. MFARs must be filed by all registered or recognized funds. The MFAR contains details of fund service providers; net 
asset values; asset size and mix; and expense information that will be used to focus inspection efforts. It is also the FSC's intention to publish aggregate data from the MFARs to inform the marketplace. Further, under SIBA, the requirement to file audited financial statements will now apply to all licensed financial services firms (such as mutual fund managers and administrators) and public funds. This will provide further information for oversight purposes and facilitate off-site supervision of licensees that are located completely offshore.

35. The FSC has very broad authority to share information with its domestic and foreign counterparts. These powers have been enhanced and the process for information exchange has been streamlined since the last assessment and the concerns identified have been addressed. There are no significant practical impediments to providing assistance to foreign regulators that need to make inquiries in the course of carrying out their regulatory activities. The FSC is a signatory to the IOSCO MMOU and now a full member of IOSCO.

\section{The full implementation of SIBA will provide the FSC with authority over} public issues of all types of securities. The provisions in SIBA set out general requirements for full disclosure in public-offering documents, the liabilities for misrepresentation, and the authority of the courts to order compensation to investors if the prospectus contains a misrepresentation. Full implementation of the regime requires development of a Public Issuers Code that would contain the details required in prospectuses. SIBA does not address take-over bids or similar transactions. However, as there are no primary market issues of securities in the BVI other than mutual funds and, thus, no market for corporate control, the fact that the FSC has no statutory authority in this area is not a weakness.

\section{The accounting and auditing standards applied are high and of an}

internationally acceptable quality. The recently enacted Regulatory Code requires regulated entities to use approved auditors and sets out criteria for approval as suggested in the previous assessment. The Regulatory Code and SIBA require financial statements to be prepared, using International Financial Statement Reporting Standards (IFRS) or another listed set of generally accepted accounting principles (GAAP) of similar quality, such as U.S., U.K. or Canadian GAAP. Audits must be performed using internationally recognized standards of audit. These changes address weaknesses in accounting and auditing standards that were identified in the previous assessment.

\section{The full range of market intermediaries will be subject to licensing under}

SIBA. Until SIBA is fully implemented, only mutual fund administrators and managers located in the jurisdiction are subject to licensing. SIBA would expand the licensing obligation to brokers; dealers; underwriters; discretionary investment managers; investment advisers; investment custodians; and operators of investment exchanges that carry on business in or from the BVI. Full implementation for securities intermediaries, other than mutual funds, requires promulgation of Investment Business Regulations and amendments to the Regulatory Code, neither of which are completed. As there are no retail securities intermediation activities being carried on at present, this gap may not be serious. Representatives of industry, with whom we met, indicated that there may be 
interest from market participants for licensing under one or more of these categories fairly soon, so the need to draft and implement the necessary instruments may become pressing in the near term. This also may require further resources-both more staff and additional training of current staff- to address these new areas.

39. SIBA provides for licensing of operators of investment exchanges. However, the regime set out in the legislation is of general application to all types of intermediaries and does not address the full scope of concerns set out in the relevant IOSCO Principles regarding secondary markets, such as review of trading rules, price transparency requirements, and management of large exposures. As there is no organized market in securities in the BVI, nor any trading or clearing and settlement system operating in or from the BVI, this raises no significant concerns. The FSC does not expect that any of these facilities will be established in the BVI in the foreseeable future. Should circumstances change, the SIBA framework may be flexible enough to allow for expansion of the requirements by regulation or Regulatory Code to address these missing elements. 